\title{
- The Epistemology of Perversion: From Pathology to Pathography
}

- The perpetually unstable nature of the fetish in theoretical discourse has been mirrored by a continuing debate on the place of fetishism within the larger realm of perversion. In an article published in 1933 in the surrealist journal Minotaure, Maurice Heine (known for his diagnoses of the Marquis de Sade) included an illustration captioned " $L$ ' Arbre des perversions." This "perversion tree" is used to demonstrate several points: its roots, forming a bolus beneath the soil and wrapped in the classificatory label bisexualisme, show irrepressible homosexual tendencies gaining ascendancy over heterosexualism as they travel upward on a phallic stalk. Each side of the trunk sports the banner parésthésies-a term proposed by Heine to abolish "ethico-religious" distinctions between the born perverse and the socialized perverti. On the side of parésethésies psychologiques we find passions qualified as perverse on account of their objects-narcissism, zoophilia, gerontophilia, necrophilia, pedophilia. These strains are distinguished from parésthésies physiologiques only insofar as repressed homosexuality plays a less significant role in their gestation. Situated on the physiological side, fetishism merits a leaf of its own sandwiched between exhibitionism and sadomasochism. What is significant about Heine's perversion tree is not the persuasiveness of its categorizations but, rather, its emphasis on the structural similarities binding each perversion to

1. Maurice Heine, "Notes sur un classement psycho-biologique des parésthésies sexuelles," Minotaure, no. 3-4 (Dec. 1933): 36 . 
its mirror opposite, pairing and cross-referencing them within an epistemological matrix. The tree also anticipates current controversies over sexual difference, for each perversion is shown originating in an unresolved sexual difference that, as it evolves, bypasses the orthodox gender differentiations of "normal" masculinity and femininity.

In attempting to frame the epistemological field of perversion, Foucault directs us to an earlier phase of psychoanalysis, to that period in the 187 os and 1880 os during which "perverse pleasure" was, in his words, subject to "psychiatrization."2 Of all the perversions classified and "entomologized" in this era, fetishism emerges as Foucault's "model perversion ... which, from at least as early as 1877 , served as the guiding thread for analyzing all the other deviations" (HS 1:154). Why did Foucault place fetishism so high up in the epistemological hierarchy of deviant sexuality? Was there something about this perversion in and of itself that attracted the heuristic skills of the early psychoanalysts? Did its kinship ties with the eighteenth-century legacy of libertinage render fetishism in an age of bourgeois moralism a return ticket to the decadent past? Did the blasphemous adjacency of object fixation to "primitive idolatry" (a degenerate cultural atavism within modern Christian civilization in the Eurocentric mind) cause fetishism to become the imperative target of social repression and correction? Or were its regressive, infantile characteristics (touching, gazing, fondling) an affront to the ideology of progressive maturation and psychosexual development historically deriving from fin-de-siècle sélectionnisme and social Darwinism?

It may have been the fundamentally harmless, gratuitous nature of fetishism that endowed it with the quality of a threatening enigma. Police reports recording that scissor assaults of fetishists on plaits of hair or patches of velvet skirt reveal how rarely physical harm was done to the (invariably female) victims. ${ }^{3}$ The motive for such peccadillos remained as elusive to law enforcers as the infa-

2. Michel Foucault, The History of Sexuality, vol. 1: An Introduction, trans. Robert Hurley (New York: Vintage, 1980), p. 43. Further references to this work will be abbreviated HS.

3. See Gustave Macé's La Police parisienne: Un joli monde (The Parisian Police: A Pretty World) (Paris: Charpentier, 1887), in which he hierarchically organized fetishists into categories defined according to stereotypical behavior: "les peloteurs" (those who stroke), "les frotteurs" (those who rub), "les éperviers" (experts at tracking their prey), "les déstructeurs" (destroyers-a particular menace to dresses and coats), "les coupeurs de cheveux" (cutters of hair-of whom Macé wrote: "In this sentimental category of memory harvesters, I question an individual who would approach young girls of ten to twelve years whose hair fell straight down or in braids 
mous acte gratuit (gratuitous act) of the Gidean sotie. Unlike Gide's brazen adolescents, however, fetishistic marauders were typically mild-mannered, pitiable, petit bourgeois who lacked the hereditary stigmata normally used to construe evidence of moral atrophication and criminal character. The "portrait of the fetishist as a young man" was modeled on the stereotype of the shy, foppish, "feminized" male whose taste for collecting betrayed an overly developed epicureanism and an attraction to the sampling of "bizarraries" (fetishists, ever since Jean-Martin Charcot and Valentin Magnan's groundbreaking article on "genital inversion" [1882] were suspected of being latent homosexuals). ${ }^{4}$ The typical fetishist was susceptible to manic passions, from bric-a-bracomania to erotomania. Though far less sinister than the sadist or masochist whose sexual appetites and proclivities, luridly cataloged in Krafft-Ebing's Psychopathia Sexualis (1886), could be satisfied only through violence, the fetishist shared with the sadomasochist a socially reprehensible propensity to "linger" (Freud's term) in the realm of foreplay. ${ }^{5}$ Digressing on the path to coital consummation, foiling civilization's righteous aim to propagate the species, he was guilty of an exemplary dalliance in gratuitous sex. ${ }^{6}$

on their shoulders. Armed with scissors, he would mutilate their silky hair by cutting half of it off" [p. 268]), and "les collectionneurs de mouchoirs" (collectors of handkerchiefs-"When one of these individuals has just picked up a handkerchief, he passes it over his lips in a passionate gesture, he breathes in the perfume and wanders off staggering like a drunkard" [p. 269]).

4. Jean-Martin Charcot and Valentin Magnan, "Inversion du sens génital et autres perversions sexuelles," Archives de Neurologie 3 (Jan.-Feb. 1882): 53-6o, and 4 (July 1882): 296--322.

5. In the section "The Sexual Aberrations" in the Three Essays on the Theory of Sexuality, Standard Edition 7, Freud placed the burden of perversity on this rather elusive notion of "lingering": "Perversions are sexual activities which either (a) extend, in an anatomical sense, beyond the regions of the body that are designed for sexual union, or (b) linger over the intermediate relations to the sexual object which should normally be traversed rapidly on the path towards the final sexual aim" (p. 150). Freud introduces an interesting notion here of normative temporality within sexual conduct. How long does it take, we are tempted to ask, before foreplay deteriorates into perverse "lingering"?

6. In his fastidious classification of perverse practices entitled Fétichistes et érotomanes (Paris: Vigot Frères, 1905), Paul Laurent offered a stereotypical portrayal of the fetishist featuring his "timid" nature and the "absurd" quality of his predilections: "The sexually perverted fetishist is therefore not a monstrum per excessem (monster by excess), like the masochist or the sadist, but rather a monstrum per defectum (monster by default). In effect, he spends himself genitally, and by a kind of amorous ectopy (transport), in an illogical, bizarre and absurd ritual, that could be considered as a sort of psychic onanism. Far from being excited sexually by venereal pleasures, he is on the contrary timid in matters of love, impotent and uninterested in the union of the sexes; genitally he sins much more of ten by default than by excess" (p. 7). 
In constructing the genealogy of these fetishist character types the pre-Freudian doctors relied not only on a collection of endlessly repeated and elaborated case studies but also on the weighty evidence provided by literature of the fetishist's continuous presence in history. La Revue Thérapeutique des Alcaloïdes (which featured a regular column on famous neurotics of the past), La Chronique Médicale (under the direction of Dr. Augustin Cabanès), and Aesculape (a glossy, well-illustrated compendium of anomaly including articles ranging from the photographic materialization of ghosts to hypertrichoses, or hairiness, in women) were among the many therapeutical journals containing studies of local or exotic strains of fetishistic obsession.

In the field of medical speculation on literary examples, the eighteenth century, widely regarded as the last age of true libertinage, held a privileged place. ${ }^{7}$ Jean-Jacques Rousseau, Rétif de la Bretonne, and later the Marquis de Sade consistently surfaced as the prototypes for nineteenth- and early-twentieth-century sexology. From Alfred Binet's interpretation of Rousseau's masochistic tendencies in his article "Le Fétichisme dans l'amour" (1887) to the reflections of the doctors Avalon and Charpentier in "Rétif de la Bretonne fétichiste" (1912), through to Havelock Ellis's discussions of "rétifisme" qua foot fetishism in his famous Studies on the Psychology of Sex (1936) and Maurice Heine's analyses of de Sade's newly discovered oeuvre, readings of eighteenth-century literary texts were legion. ${ }^{8}$ We may infer from them a consistent hermeneutic

7. The medicalization of the eighteenth century by the nineteenth century took place on two levels: the first involved reconceiving libertine sexual practices (adultery, libertinage, anal eroticism, etc.) as perversions ("morbidity," "erotic madness," "genital inversion," etc.). The writing of Jean-Martin Charcot and Valentin Magnan, A. Moll, Benjamin Ball, Paul Laurent, Charles Féré and Paul Garnier, and the Goncourt brothers contributed to this sociomedical reconstruction. The second level was fostered primarily by Dr. Augustin Cabanès, who wrote on "the secret cabinet of history peeped into by a doctor" (1897). He was particularly well known for his psychophysiological diagnoses of Rousseau, Marie Antoinette, and Citizen Marat.

8. According to the Baron Octave Uzanne, a period of "Restifomania" began in 1883 and developed into a debate over foot fetishism (which would last well into the 1930s) after Binet's article appeared. Doctor Louis fixed the terms of the controversy in his analysis of Le Pied de Fanchette and Le Joli Pied ("Un Romancier fétichiste: Restif de la Bretonne," La Chronique Médicale, June 1904). Refusing to accept the characterization of Rétif as a foot fetishist, John Grand-Carteret (an eminent critic of caricature) accused Dr. Louis of being among the "déboulonneurs de grands hommes" (debunkers of great men) in his preface to an abridged edition of Monsieur Nicolas (1911). Dr. J. Avalon resumed the debate in Aesculape, Apr. 1912, pp. 89-93, and Doctor Louis Barras devoted an entire thesis to the subject: Restif de la Bretonne: Fut-il fétichiste? (Montpellier, 1912), in which he argued, according to Havelock Ellis, 
strategy toward the definition and interpretation of fetishism that mediates between historical periods and literary genres.

Alfred Binet's seminal essay "Le Fétichisme dans l'amour" was the first study to transpose the concept from religion (as in Charles de Brosses's Du Culte des dieux fétiches, ou Parallèle de l'ancienne Religion de l' Egypte avec la Religion actuelle de Nigritie of 1760) and economics (Marx's Capital, 1867) to psychology. Binet is known primarily for his invention of the modern intelligence test; his work on fetishism, some fifteen years prior to his research on craniometry, seems to belong to a separate career. ${ }^{9}$ Though informed, like the work of Cesare Lombroso (taxonomist of the physiognomical traits of "born prostitutes" and criminals) and Alphonse Bertillon (inventor of the identity card and fingerprint test), by a concern with descriptive measurement, the article eschews a narrow statistical approach. Binet invented a fetishism indebted to Enlightenment theories of classification and comparative religion, but modern in its psychosexual application.

This modern aspect, the fin-de-siècle circumstances under which his article was written, has been traced to a debate with Richard von Krafft-Ebing over the origins and causes of perversion. KrafftEbing had subscribed to the conventional "heredito-degenerescence" theory, believing perversion to be essentially innate or socially induced. Binet, taking issue with the blind belief in external causation, proposed a more purely psychological explanation, attributing the eclectic choice of fetish objects to some traumatic early sexual impression. ${ }^{10}$

Opening his essay, Binet offered a synopsis of fetishism's etymological origins that would become a kind of stock point of departure for future writers on the subject. ${ }^{11}$ Fetisso, the pidgin version,

that Rétif's fetishism was a general condition (Havelock Ellis, From Rousseau to Proust [London: Constable, 1936], pp. 149-50, 172-75).

9. For a precis of Binet's career as the father of the modern intelligence test, see Stephen Jay Gould, The Mismeasure of Man (New York: Norton, 1981), pp. 146-55. Like many doctors of the period, Binet also dabbled in literature, collaborating with André de Latour de Lorde on a number of melodramas featuring the domestic havoc caused by hereditary madness (see L'Obsession [1905], L'Horrible Expérience [1909], L'Homme mystérieux [1910], Les Invisibles [1912], and Un Crime dans une maison des fous [1915].

10. See Elisabeth Roudinesco, Histoire de la psychanalyse en France, vol. 1: $1885^{-1939}$ (Paris: Seuil, 1986), pp. 235-38.

11. Dr. Paul Laurent, for example, began his Fétichistes et érotomanes (1904) with the same linguistic derivation from the Portuguese trading term feitiço, or native charm. 
referred, as Binet pointed out, to the idea of an "enchanted object" that mysteriously held sway over individual destiny (from fatum). Borrowing Max Müller's pejorative allusion to the role of cult artifacts within pagan ritual and superstitious belief, Binet ascribed the term to a specific form of erotomania. Focusing on the role of the "object of obsession" in the stimulation of desire, he replaced Stendhal's celebrated crystallization with his own more shamanistic divinization, thus reinforcing a theoretically novel analogy between erotomania and cult worship: "The term fetishism, it seems to us, is rather appropriate for this genre of sexual perversion. The adoration these patients exhibit toward inert objects such as the nightcap or the bootnail resembles on every level the adoration exhibited by the savage or Negro toward fish-bones or shiny pebbles, with this single important difference that, in the cult of our patients, religious adoration is replaced by sexual appetite." 12 Binet thus emphasized the fractal, metonymic nature of the fetish, religious or sexual. Whether inanimate (the night cap, the apron, the nail of the shoe) or alive (red lips, an alluring curl of hair, an eye or mouth), the fetish was partial; a detached spot of intense visual cathexis. Foreshadowing Freud (though offering nothing as sophisticated as Freud's causal link between castration anxiety and phallic substitution), Binet placed the fetish in a signifying chain of synecdoches marking the displacement of genital desire to objects and hearkening back etiologically to a moment of sexual prehistory when the erotic idée fixe was indelibly scored on the psyche.

Inadvertently throwing into relief the dangerous ease with which passional devotion could give way to erotic interest (thereby exposing the fragile epistemological grounds dividing religion from sexuality, or "normal" from perverse desire), Binet went on to analyze the operations of fetishism in the writings of Jean-Jacques Rousseau. Rousseau's compulsive lying, strange erotic tastes, and erratic volleys of abuse toward the love object rendered him an

12. Alfred Binet, "Le Fétichisme dans l'amour," Revue Philosophique (1887): 144. Further references to this essay will be abbreviated B. Binet's identification of fetishism at the heart of religious worship continued to be endorsed by a subsequent generation of sexologists, including Freud and Magnus Hirschfeld, who wrote: "The transposition of sexual impulses into religious impulses, their mutual substitution, is only possible by virtue of a certain kinship existing between religious and sexual ecstasy. Just as the lover "adores" his beloved, calls her his "angel," his "idol," so does the love of the Savior, of the Virgin Mary, of the saints or the adoration of idols and fetishes, appear of ten to be a substitution of an erotic equivalent" (Le Corps et l'amour [Paris: Gallimard, 1937], p. 26). 
exemplar of aberrant consciousness. Well served by Rousseau's abject wish fulfillment (his professed wish to lie at the feet of an imperious mistress), Binet pathologized his literary masochism, linking the posture of submission (assujetissement) to fetishistic paradigms of idolatry and idealization. Binet thus transformed Rousseau's narrative deviousness into a psychiatric model of sexual deviance.

Though according to Binet almost any work of romantic fiction might off er commonplace examples of the lover's frenzied hypostatization of his beloved's relics (her handkerchiefs, a piece of her dress, a book whose cover had been caressed by her hands), Rousseau's Confessions were for him particularly significant from a medical viewpoint. In them the author took the crucial step toward perversion, for the choice of privileged icon could no longer be seen as simply the result of its direct or contiguous connection to the actual body of the beloved. The relic, intransitively inscribed within the consciousness of the fetishistic lover, was revered in and for itself. No longer just the signifier of an absent totality, the material object was severed from the woman's body and actually preferred to the living self to which it originally belonged. "Amorous fetishism" Binet surmised, "has a tendency to detach completely, to isolate (the object) from anything separating it from its cult-worship, and when the object is part of a living person, the fetishist tries to render this part an independent entity" (B 263). Freestanding, self-enclosed, and abstracted from context, Binet's fetish object bore the signs of cutting, a violent image that, in addition to prefiguring Freud's association of fetishism with castration, underscored the importance of the synecdochic gaze.

For Binet, the epistemological difference between the workings of synecdoche in fetishism and in normal love was determined by the degree to which individual parts assumed semantic autonomy within the lover's code. When the beloved herself was fragmented and objectified, outmatched by the allure of her cosmetic appurtenances, then ordinary passion crossed over into fetishism:

Rousseau confessed that seamstresses, maidservants, and shopgirls hardly tempted him; he needed women of class. "It's not at all the vanity produced by estate or rank that attracts me, it's sensual delight; a better preserved complexion; a finer, better-made dress, a daintier shoe, ribbons, lace, hair better dressed. I would always prefer the less pretty one as long as she had more of all of that." With his customary precision, Rousseau signaled the key factor in his predilection when he said that it was not a matter of vanity but of sensual pleasure. (B 161) 
Capitalizing on Rousseau's privileging of volupté, or unadulterated pleasure, Binet drew attention to Rousseau's onanistic mode of object worship. The discourse of pleasure, so enthusiastically elaborated by the Goncourt brothers with reference to the mores of Rousseau's century, was here specifically identified with a haptic technique of perversion. Touching and stroking the nearest object at hand, obtaining titillation from a piece of ribbon or lace, the fetishist implicitly valorized object contiguity (metonymy), or what Binet characterized in terms of the twin principles of abstraction and generalization. ${ }^{13}$

These pathological tropes of perversion emphasized by the doctor in Rousseau's text were systematically built up to form a kind of "Rousseau case-history," crediting the philosophe with the invention of a psychic fetishism that went beyond the extended metonymy of the body. Following step-by-step the narrative genesis of Rousseau's famous discovery of masochism at the hands of his gentle disciplinarian Mlle Lambercier, Binet dilated on the fetishist's propensity for "erotic rumination"- that is, his ability to project his object fixation to the realm of intellectual and emotional obsession (B 253). Abjection, that condition of total ontological submission that Rousseau would tirelessly seek to reproduce, represented a highly refined version of the fetish: "What Rousseau loves in women," Binet observed, "is not just the puckered brow, the raised hand, the severe look, the imperious attitude, it's also the emotional state of which these attributes are the exterior translation; he loves the proud, contemptuous woman, who crushes him at her feet with the weight of her royal rage" (B 256). Unlike Rétif de la Bretonne, apparently content with a simple substitution of the pretty foot for the totalized body, Rousseau found his pleasure in a foot fetishism that was a significant step removed from the physical; an idealized mode of mental flagellation analogous to the monk's mortification of the flesh or the roué's self-destructive quest for moral debasement. "To love, say the mystics, one must suffer" (B 258), Binet wrote, a phrase that in its turn would become a kind of motto for Dr. Cabanès in his treatise La Flagellation dans l'histoire et la littérature (1899).

For Binet, this relationship between image making and orgasmwhat he called la dynamogénie - not only indicated Rousseau's parti-

13. See Edmond and Jules de Goncourt, L' Amour au dix-huitième siècle (later included in La Femme au dix-huitième siècle) (Paris: E. Dentu, 1875). 
ality for "erotic rumination," a pathological condition identifiable in most perverts, but also served to characterize an entirely new genre, that of literary perversion. Without exactly characterizing it as such, Binet sketched a theory of perverse writing that, ostensibly developed on behalf of medical diagnosis, inexorably expanded to comprise the domain of writing and reading as a whole. For the normal man, he surmised, the most paltry real experience would be superior to the jouissance derived from masturbatory fantasy. For the ruminants, however, who subversively reversed the hegemony of the Real over the Imaginary, images were rendered as self-sufficient mechanisms in ejaculatory production. Drawing the now-obvious analogy between sexual fantasizing and writing, he qualified what Freud would call sublimation as a form of textual perversion:

- The same effect of dynamogeny is obtained,... by the habit of writing, that is to say by objectifying thought on a piece of paper; the mental image is in this case more intense; it has the effect on the very person who gave birth to it of seeming to come from outside. Moreover, one must not forget that spoken language, and especially written language, is a marvelous instrument for analyzing thought; the subject, seeking through this means alone to write his dream, is obliged to analyze it; a weak, vague image no longer satisfies him; everything must be sharpened and nuanced under the influence of the pen. (B 270)

In this way Binet unearthed the fetishism submerged within writing itself, associating the process of contour sharpening (a kind of focalization) with the very essence of erotic fixation. This effect of sharpening the lens, of stabilizing the image as if plunging it into a chemical bath, yielded, moreover, interesting implications for the genre of realism still prevalent as a literary fashion of the belle époque. Commenting on the links between realism and the stylistic technique of hyperamplification, Binet clearly articulated a role for the eroticized detail in fiction: "Witnesses to a fact of real life," he wrote of writers in general, "they seek to amplify it in order to make their readers more sensitive to it." Analyzing Adolphe Belot's best-seller La Bouche de Madame X ... he argued that the writer "had probably seen a benign real-life case of fetishism but had exaggerated the phenomenon for the sake of the novel" (B 272).

In his evocation of real-life perversions writ large, Binet was undoubtedly referring to the way in which Zola, Maupassant, and the Goncourt brothers (among others) had raided the medical archives as source material for their experiments in clinical realism. 
Even when there was no proof that nineteenth-century authors had consulted scientific documents, it is fairly evident that they appealed to the public's intuitive grasp of psychopathology. Literary works specifically cited by Binet-Gustave Droz's La Femme gênante; "La Maison du vent," by Dumas fils; Barbey D'Aurevilly's Vellini; and Georges Rodenbach's Le Carilloneur-all relied on fetishistic symptoms that were presumably recognizable to the lay reader. In this sense it is perhaps no wonder that time and again, in the supposedly scientific case studies of the doctors, literary examples were adduced to support experimental evidence rather than just the reverse.

In his suggestion of a pathology of realist stylistics, in his insinuation that all writers are potential fetishists, Binet thus expanded the epistemological parameters of perversion while inviting further speculation on the repertory of forms that textual fetishism might assume. By characterizing fetishism as an extreme genre of normal love Binet opened the way for all the tropes of amorous discourse to be seen as themselves fetishistic. Divinization, synecdoche, abstraction, depersonalization, and psychic fixation emerge as the preeminent defining features of fetishism, despite their appearance in normal love as well. With degree the only significant differentiating factor, the risk of "perversion" loomed perilously near.

No doubt sensing the need to remarginalize this outlaw edge of sexuality, Binet had recourse to further medicalization of the lover's discourse. His strategy, once again highly literary, consisted of defamiliarizing the commonplace bourgeois codes of romanticism: the conventions of idolatry, idealization, and hyperbole. Stendhal's De l'amour, for Binet an omnipresent intertext, thus became in his hands a manual detailing the stages and modalities of fetishism rather than seduction. The magical déclic, the sign on the lover's body that ignites attraction and fuels the quest to reproduce the image in the Other (even a defect, a disfiguring smallpox mark, could function in this way according to Stendhal), became within the confines of Binet's theory the fixative moment, the fetishistic primal scene to be found both in every normal ritual of enamoration and in its representation. Without knowing, perhaps, where his reading of textual perversion would lead him, Binet made a "pervert" of Everyman: lover, reader, and writer.

Variety and instruction-these values ascribed to the linguistic anomaly picked up and assiduously stored over the years like an 
amusing bagatelle by the master nineteenth-century lexicographer Emile Littré-may be seen as the twin raisons d'être for a clinical realism that pervaded late-nineteenth-century prose.

- Like a highly experienced doctor, who, perusing the diary of his cases at the end of his career, pulls out those he considers to be particularly instructive, so I have opened my journal, my dictionary, that is, to select a series of anomalies which struck me or embarrassed me even when I wrote them.... This proliferation of little facts, dispersed throughout my dictionary, are here subject to sustained scrutiny. They have the interest of variety, and at the same time, since they are facts, they have the interest of reality. Variety amuses, reality instructs. ${ }^{14}$

In this way Littré's pathologie verbale, with its didactic "little real" placed on exhibit, exemplifies the word itself made stigma. Connoting an image of language "on the couch," or in the clinic, this expression was also symptomatic of a zeitgeist enamored of scientisms impossible to subsume under one rubric yet uniformly maniacal even in their eclecticism. A unique coalescence of positivism, Darwinism, sociopathology, tabloid reporting, medical jurisprudence, anthropo-criminology, national chauvinism, pessimism (Schopenhauer), exoticism, racism, mysticism, sexology, naturalism, and decadence fomented an intellectual culture in which Binet's essay on fetishism was fully contextualized..$^{15}$ To enable us to appreciate the extent to which fetishism, as a form of verbal pathology, became identifiable as a style of writing legible to a broad reading public, a brief review of this medico-literary culture may be helpful.

Following in the French positivist tradition of physiological psychology, from Balzac's Physiologie du mariage (1829) to Paul Bourget's Physiologie de l'amour moderne (1889), Remy de Gourmont's book on the "physic of love" (translated as The Natural Philosophy of Love) typifies the psychobiological tendency within nosological realism at the turn of the century. Written between 1901 and 1903 his "essay on sexual instinct" heralds the new field of what he refers to as "sexual ethnography." Physique de l'amour places itself under the sign of the maxim more bestiarum (bestial love) —-"love is profoundly

14. Emile Littré, Pathologie verbale ou lésions de certains mots dans la cours de l'usage (Paris: Société des Amis de la Bibliothèque Nationale, 1986), pp. 8-9.

15. Though it would require a separate study to investigate fully the myriad intellectual genealogies present in this mid-fin de siècle, a brief overview (following on the heels of important historical studies of crime, medicine, and madness by Elisabeth Roudinesco, Robert Nye, Jan Goldstein, Ruth Harris, and Roger Williams) may illuminate sources of a nosological consciousness inclusive of fetishistic realism. 
animal, and that is its beauty."16 De Gourmont documented the sexual life of plants and animals and introduced the word scissiparity as a kind of presciently psychoanalytical concept mediating between ego-splitting, sexual difference, and gender instability: "sexual attitudes are attributed by Nature to both sexes: there is no ordained male or female role,... each can don the same costume, wear the same mask, wield the same weapon, tool or sabre,... and short of consulting Life's archives, we may never know if a sex is masquerading or performing a natural role" $\left(P 6_{1}\right)$. The great travesty, the grand "parade" of seduction common to animal and human species alike, signified for de Gourmont that which was "true" in love. Ludic sexuality, recast through Darwinism as an appetite-enhancing ruse of nature, emerges as the norm of love's "physic" (or motor) at the expense of modesty, chastity, and asceticism. These last, so vaunted by religion, are dismissed as unnatural acts. De Gourmont would later parody this epistemological inversion of normal and perverse in his play Lilith (1906), in which the human race is perpetuated only when Satan's mistress solicits fecundation from a timorous Adam. Quivering, panting, and moaning, drawing Satan himself in vulva infernum, Lilith personifies an essentialist vision of the animal nature of the female much like Rachilde's throbbing heroine in L'Animale (1903), who sees herself in the mirror as a woman-beast, with red eyes and paws, pendulous breasts, and a "splendid fleece." 17

Citing Schopenhauer, who had used as an analogy to the external laws of nature the example of a putrid flower (arum muscivorum) that could "fool" cadaver-seeking flies with its scent, Remy de Gourmont associated the mating instinct with the metaphysical workings of a blind, indifferent will. In its fusion of pessimism, natural philosophy, and sexology, Physique de l'amour could be bracketed on the literary side by Zola's La Bête humaine (featuring Lantier's struggle against innate urges to rape and kill) and Proust's Sodome et Gomorrhe (opening with the famous fertilization scene between the bumblebee [Jupien] and the orchid [Charlus]). On the medical side, it fit into a canon including Prosper Lucas's Traité de l'hérédité (1850); Herbert Spencer's Principes de psychologie (1855); Auguste Bénédict Morel's Traité des dégénérescences (1857); Théodule Ribot's

16. Remy de Gourmont, Physique de l'amour: Essai sur l'instinct sexuel (Paris: Les Editions 1900, 1989), p. 17. Further references to this work will be abbreviated $P$.

17. Rachilde (Marguerite Valette), L'Animale (Paris: Mercure de France, 1903), p. 307. 
De l'hérédité (1872), Maladies de la volonté (1884), and La Philosophie de Schopenhauer (189o); Cazalis's Le Livre du néant (1872); Max Nordau's Dégénérescence (1893); Jules Dallemagne's Dégénérés et déséquilibrés (1894); Emile Laurent's L'Amour morbide (1895); Charles Féré's L'Instinct sexuel (1899); and Otto Weininger's misogynistic Sexe und Charakter (1904).

In addition to providing the medical underpinnings for a positivist literary heredito-degenerescence theory of character popularized by Hippolyte Taine and Zola, this corpus raised new questions pertaining to the role of the senses in aesthetic appreciation (as in Henri Bergson's study of laughter) that in turn intersected with Krafft-Ebing's notion of physiological fetishism. Citing Binet and Max Dessoir (who published an article in German on the fetishism of love), Krafft-Ebing delineated the broader sphere of fetishistic sensualism - the idolatry of physical qualities in the Other, whether eye, voice, smell, or touch. Théodule Ribot's description of a kind of "inner haptic" (Gemeingefühl) — an "internal touching by which we are made aware of the state of our organs, the tension of our muscles, the degree of our lassitude or sensual delight"-may be interpreted in this light as a fetishism of the interior body. ${ }^{18}$ As if taking this interiorized fetishism as his program, the exoticist novelist and poet Victor Segalen shuttled conceptually between internal and external aesthetic phenomenologies of the body in a thesis outline planned while he was a medical student in 19oo. The first chapter was to be dedicated to a comparison between clinical and naturalist case histories; the second proposed an examination of manias, hysterical fits, and hallucinations in novels such as Salammbô, Le Horla (an anagram of Dr. Cazalis's pen name, Lahors), La Faustin, and $A$ rebours. A third intended to explore "sensorial synaesthesias" in the symbolist school. Heredity and degenerescence as portrayed in Zola's Le Docteur Pascal, drug use and alcoholism in works by Daudet and Théophile Gautier, the morbid psychology of crowds in Gérard Hauptmann's Les Tisserands, and, perhaps most interesting, a reading of Pierre Loti's Le Rêve as a case study of déjà-vu-each was allotted its section in this ambitious project. In the resulting book, Les Cliniciens ès lettres, Segalen (though considerably narrowing the focus) argued convincingly that realists and naturalists had made the medicalized body a topos of destiny in the

18. Théodule Ribot, L'Hérédité psychologique (Paris: Librairie Germer Baillière, 1882), pp. 90-91. 
novel. In this regard he quoted Edmond de Goncourt's letter to Zola on the day following Jules de Goncourt's gruesome death from syphilis, referring to how detailed medical descriptions of the disease presented in their novel Charles Demailly retrospectively seemed to have uncannily foretold the untimely death of the author: "When we wrote Charles Demailly together, I was more ill than he was. Alas! He has hanged himself since. Charles Demailly! It really is most bizarre, the fact that he wrote his own story fifteen years before!" 19

Constituted on the one hand by the writer's appropriation of medical jargon (de Gourmont lamented that while physicians in Molière's time spoke Latin, in his own they spoke Greek), and on the other by a scientific tradition sensitive to the literariness of the medical gaze (an astonishing number of doctors published novels under pseudonyms), the medico-esthetic stylistics of anatomy were also reinforced by a proliferation of scholarly studies concentrating fetishistically on body parts. Gilles de la Tourette's Traité clinique et thérapeutique de l'hystérie (1891-95) contained, for example, a chapter on "the hysterical breast" that chronicled the case of a patient whose facial blush was matched by mammarian spotting and swelling. ${ }^{20}$ Paul Richer, an artist who collaborated with Charcot in developing an iconography of seized-up postures and morphological malformations in hysterics, also played a crucial role in generating a visual lexicon of the stigmata-riddled medical body. Subscribing to the principle of similia similibus curantur (the same are cured by the same), Richer took his cue in providing exact copies of the hysterical body from "primitive" artists who depicted pathological divinities afflicted by the wounds they were supposed to heal. In addition to fashioning plaster casts of "hysterical contractures" (le pied bot, le pied tors) he left writings with titles such as "Notes on the Fold of the Buttocks" (1889) that seem now like virtual parodies of naturalist depictions of the convulsive body part. Karl Kraus's quip, "There is no more unhappy being under the sun than a fetishist that pines for a boot and has to content himself with an entire woman," could easily be applied to Charcot and his disciples, all obsessively dedicated to the clinical methodology of "pictorial" focalization on an

19. Edmond de Goncourt as cited by Victor Segalen, Les Cliniciens ès lettres (1902; Montpellier: Fata Morgana, 1980), p. 76.

20. Gilles de la Tourette, Traité clinique et thérapeutique de l'hystérie, vol. 2 (Paris: Plon, 1895), p. 492. 
isolated part of the body. ${ }^{21}$ Clearly, the supernatural severed hand in Maupassant's "La Main écorché" (1875) and Zoë Bertgang's foot in Wilhelm Jensen's Gradiva: A Pompeiian Fantasy (1903) formed part of a larger episteme of fetishism grounded in medico-anatomical synecdoche.

Within the encompassing genre of nosological realism, fetishistic synecdoche may be distinguished from medicalized description in general by its textual eroticism. Inanimate objects registered as erogenous zones in the narrator's eye, bodily extremities tinctured with redness or "split" in a mock-staging of castration, repulsive details, miming the fetishist's putative tendency to wallow in disgust, and physical mutilation, these are among the signs of a metonymic poetics encoded as fetishistic.

From Monsieur Nicolas's high-heel worship to Emma Bovary's revered slipper or Thérèse Raquin's attention-snatching boot, foot fetishism has attained a literary "pedigree" in the history of French literature. But rather than thematically catalog such proverbial phallic symbols as they appear in great literary works, I will examine a number of less familiar texts written in the "low-rent" realist mode. Récits and novellas by writers such as Adolphe Belot and Octave Mirbeau offer a clarified image of what I mean by the expression "fetishistic fiction," because their generic contours so closely resemble those of the archival case history. Unheroic texts of conf ession and talking-cure, parables of base instinct and perplexing longing told by anonymous narrators, stories of mental illness and hysteria cataloging in detail the full range of morbid symptoms, these works of a countercanon blur the line between fiction and nonfiction. $^{22}$

21. Karl Kraus as cited by Jean Bellemin-Noël, Gradiva au pied de la lettre (Paris: Presses Universitaires de France, 1983), p. 258.

22. Literary anecdote peppered the medical case history. As an example, Dr. Paul Moreau de Tours's Des Aberrations du sens génésique (Paris: Asselin, 1880) traced erotomania to the allegory of Love, seen by the ancients as a kind of vengeance of love (loving too much). The doctor refers to classical tales of a Greek who became so enamored of a Cupid statue that he defiled it with his seed and left an offering of a crown. The Delphic oracle ordered his release because he paid for his pleasure. He also cites Lucan and Saint Clement of Alexandria, who told the story of a young man who falls in love with a Venus by Praxiteles, hides at night in the temple, and sullies the goddess in an outrage to public morals. 
If one looks first at the proximity of clinical case histories to fiction, Freud's analyses of Dora, the Wolf-man, and the Rat-man stand out as extraordinary models of psychoanalysis as literature. But even the earliest recorded case histories of fetishism reveal a clear affinity to their literary counterparts. Charcot and Magnan's "Inversion du sens génital et autres perversions sexuelles" included the tales of several patients who ejaculated uncontrollably at the sight of shoenails, aprons, and nightcaps. Case 4, concerning the lover of bonnets de nuit, resembles a short story with its minute attention to the interests and habits of family and milieu. We learn that the subject's father loved books, that his sister frequented the theater, that his rebellious brother became a coachman, and that M. X himself was a collector of bibelots. This seemingly irrelevant background adds a narrative suspense to the ensuing chronicle of the patient's defeat of conjugal impotence through the fantasy of a wrinkled lady in a nightcap. ${ }^{23}$ As in many of Krafft-Ebing's case studies, this narrative of fetishistic ritual approaches the comedic genre. Georges Lanteri Laura has pointed out that whereas records of masochism and sadism "conserve the dignity accruing to a narrative of pain," accounts of fetishism and exhibitionism always border on the ridiculous: "to risk so much for so little seems grotesque and pitiful; fetishistic clients give off the impression of being had, of paying too much for a paltry illusion.,"24

If comedy emerges as the prevailing genre of the authentic case history, then irony, its close relation, seems to be the dominant mode of case-history fiction. Consider, for example, Adolphe Belot's La Bouche de Mme X..., one of Binet's important paradigms of fetishistic narrative. Belot was a society writer whose best-sellers, sporting titillating titles such as Les Baigneuses de Trouville, La Maison centrale des femmes, La Bossue, and La Sultane parisienne were of ten set in brothels. La Bouche de Mme X... takes place in a specialty house of prostitution, its atmosphere of intimacy enhanced through firstperson narration. The central character is a ladies' man, an expert on all international types of women, and a connoisseur of the female mouth. He is also a personal friend of Charcot, who informs him that his enigmatic passion makes him "a remarkable subject." The novel opens with the narrator's reception at the

23. Charcot and Magnan, Inversion du sens génital et autres perversions sexuelles, pp. $30-32$.

24. Georges Lanteri Laura, Lectures des perversions: Histoire de leur appropriation médicale, (Paris: Masson, 1979), p. 43. 
brothel, where he is a favored habitué. To his demand for something different, the madam proposes a society woman who seeks the transgressive pleasure of prostitution but will consent to submit only on the condition that strict rules of secrecy be observed. She will remain veiled, able to inspect the gentleman without his being able to do the same. Here the novelty obviously lies in the conceit of doubled, gender-reversed voyeurism, with the male viewer becoming, in this match, the object of a female voyeur.

When he enters the room, the narrator perceives an elegant form swathed in silk, velvet, and lace, whose only visible facial attribute is a mouth. The spectacle provides an example of scotomization, or visual distortion: veil and gloves cut the face, obscuring it from view. The framed mouth, magnetizing the reader's gaze, comes to the fore in hyperfocus. More than just a "reality effect" (an illusion of reality built up by a mass or concatenation of seemingly useless little notations), this detail acts as a spur or point of entry (point tichique) into the symbolic order of desire. As an eroticized synecdoche the mouth decomposes as a unified image the closer we come, causing the eye to swim in a miasma of undulating smaller synecdoches that interlock and pull the reader deeper into desire:

- Cette bouche encadrée dans le haut par le voile noir et dans le bas par des doigts gantés de chevreau, appuyés sur le menton, ressortait superbe, voluptueuse, lascive. Elle était grande, franchement dessinée, nettement arrêtée aux coins, où apparaissait un léger duvet, un duvet de blonde. Les lèvres épaisses, rouges, écartées l'une de l'autre, celle du haut relevée comme un bourrelet, s'ouvraient librement, largement sur des dents blanches, solides, bien rangées. Oui, c'était bien la bouche que j'avais toujours désirée. J'en avais beaucoup connu, beaucoup aimé, et je n'avais jamais pu trouver celle-là.

This mouth, framed above by the black veil, below by fingers gloved in kid resting on her chin, emerged superb, voluptuous, lewd. It was large, clearly outlined, cleanly demarcated at the corners, where the lightest down, the down of a blond, could be perceived. The red, thick lips, drawn apart one from the other, the upper one raised up like a cushion, opened freely, widely onto white, solid, perfectly arranged teeth. Yes, it really was the mouth that I had always desired. I had known many, loved many, but I had never been able to find this one. ${ }^{25}$

25. Adolphe Belot, La Bouche de Mme X... (Paris: Dentu, Librairie de la Société de Gens de Lettres, 1882), p. 120. 
Fighting to restore a vision of totality as a means of overcoming the castratory visual bait of the scotomized face, the narrator struggles to glimpse beneath the veil. His efforts prove futile, and worse, the mouth remains inanimate, inert, and closed. ${ }^{26}$ The part for whole symbolism here is hardly subtle, but it illustrates the way in which fetishistic synecdoche relies on a gendered scopic poetics: a voyeuristic mise-en-scène, framing conceits (the veil), visual distortion (the mouth appears temporarily out of focus), foregrounding of a singular detail ("I had known many, loved many, but I had never been able to find this one"), and excessive libidinal expenditure for the sake of a frozen, idealized image (the narrator embarks on a feverish quest for the mouth, taking him through dozens of women).

The detail also functions fetishistically in the mise-en-abyme or "hall of mirrors effect." An interesting example of this technique in which the fetishistic synecdoche is politicized rather than eroticized may be found in François Coppée's article "Fétichisme" (Le Journal, December 15, 1894). Coppée satirizes the fetishism of national heroes in the kitsch artifacts of patriotic culture, specifically as it pertains to the national cult worship of Napoleon. The officer who can smoke only a pipe emblazoned with the profile of the conqueror, or the Grand Army veteran who can take his tobacco only out of a tin with Napoleon's hat on it, must, he argues sardonically, be accused of pagan idolatry. He recounts how in passing the window of a village cabaret, he catches sight of a vial (forgotten and covered with dust), sporting a picture of the "brav' général." On closer inspection, he discovers that the image represents General Boulanger. "Forgotten so soon, though it was only yesterday that his star shone so high!" he thinks to himself, deciding that "fetishism for fetishism, I prefer that of the Grand Empereur."

26. The rest of the story proceeds as follows. Unable to possess the mouth, or to discover the identity of the unknown woman, the narrator enlists his friends to help him find the mouth. He checks from woman to woman, discarding the rest of their bodies in his comparative inspection of a single trait: "in short, it wasn't my mouth, or rather hers, let's not confuse them" (La Bouche de Mme X... 163). In despair, he repairs to the country for a rest cure. While there, he is introduced to a countess whose mouth he thinks he recognizes, but by now he is suspicious of wish-fulfilling illusions: "I was obviously mistaken, this devil of a mouth had obsessed me for so long that I saw it everywhere" (La Bouche de Mme X..., 183). Upon learning that she has just spent three months in Paris, he recovers hope and even thinks he discerns a ray of blush on her face. During a soirée, he spies on her, hoping to catch her looking for him. As they dance, he feels he recognizes the forms of "the goddess." A protracted period of disbelief mingled with credibility ensues until finally he elicits her confession. Avowing that she was driven to the brothel because an impotent husband was unable to satisfy her, she collapses into the arms of the narrator. The book ends with mouth on mouth. 
Synecdoche, as this example shows yet again, plays a crucial role in the fetishistic récit, although in general I would argue that it must be distinguished from the blazon insofar as the fetish, as Kant pointed out, implies a degraded, purely materialist sign, nonrepresentative and cut off from the organic whole. In his short story "Vernissage," Octave Mirbeau emphasized this mutilated, debased poetics, personifying what Lacan called "the phantasm of the dismembered body" (le corps morcelé) in the character of an overzealous surgeon. Docteur Doyen becomes so famous as a "body sculptor" that fashionable women beg him to cut off their limbs (disembodiment as a work of art). ${ }^{27} \mathrm{~A}$ similar theme occurs in Mirbeau's early novel Le Calvaire in which the painter Lirat mutilates the body of an allegorical Venus. In the manner of one of Courbet's corpulent nudes, she is presented as coming out of a dark crevice of shadow, carried up on the wings of a beast, her body thrown back, her thighs covered with folds of fat and beads of greasy flesh, her stomach gaping, and her expression avid, greedily "all mouth." This grotesque image is set off against a crowd of leering old men with convulsed eyes and drooling mouths, a send-up perhaps, of "Susannah and the Elders.""

Mirbeau's grotesque realism devolves consistently around the body which seems to speak its sufferings to the eye. In the short story "Piédenat," a mother lives with her son in the apartment of a cocotte. The narrator's gaze conspicuously zooms in on her repulsive hand-symbol of swallowed pride and resignation to vice: "Sa main surtout attirait mon attention, une main courte et grasse, creusée de fossettes profondes, dont les doigts semblaient de caoutchouc, une patte répugnante de bête visqueuse qui paraissait faite exprès pour tripoter de sales choses [It was above all her hand that attracted my attention, a hand short and fleshy, furrowed with deep crevices, the fingers like rubber; it was the repugnant paw of a clammy beast that seemed made for fingering dirty things]." 29 A variation of this scopic detailism recurs in "LOctogénaire," the gruesome tale of a denatured son who forces his aged mother to pose naked for painters. She assumes the posture of shame: "Ses mains et une partie des avant-bras plongeaient entre les cuisses rapprochées, pour cacher le bas du ventre et jeter un voile

27. Octave Mirbeau, "Vernissage," Le Journal, Feb. 16, 1902, repr. in Des artistes (Paris: Union Générale d'Editions, 1986), pp. 400-405.

28. Octave Mirbeau, Le Calvaire (Paris: Union Générale d'Editions, 1986), p. 150.

29. Octave Mirbeau, La Pipe de cidre: Oeurres inédites (Paris: Flammarion, 1919), p. 27 . 
d'ombre épaisse sur la nudité attristante du sexe [Her hands and a part of her forearm were plunged between her squeezed-together thighs to hide the end of her stomach and to throw a veil of thick shadow over the pitiable nakedness of her genitals]." ${ }^{30}$ As in $L a$ Bouche de Mme $X \ldots$ a visual framing technique is used to concentrate the gaze, and as in the example of the painter Lirat in $L e$ Calvaire the ocularizing conceit of the painting itself guarantees a kind of self-reflexivity to the topos of looking. Lacan theorized this "laying down of the gaze" before a riveting detail:

- The painter gives something to the person who must stand in front of his painting which, in part at least, might be summed up thus-You want to see? Well, take a look at this! He gives something for the eye to feed on, but he invites the person to whom this picture is presented to lay down his gaze there as one lays down one's weapons. This is the pacifying, Apollonian effect of painting. Something is given not so much to the gaze as to the eye, something that involves abandonment, the laying down, of the gaze. ${ }^{31}$

In the descriptions cited thus far, Mirbeau clearly makes a comparable overture-“you want to see, well look then!"-but it is a taunt rather than an invitation. The detail that he proffers to the eye is morbid, chilling. Far from being the rewarding "glance" of light coming off an apple or candlestick in a Dutch still life, or the "pacifying, Apollonian" detail in which the aesthete's oculus luxuriates, his fetishized synecdoches resemble "shots" at the object that make the eyes smart afterward. Whether comic or tragic, alluring or repulsive, the visual pinprick of the detail constitutes an essential feature of nosological realism.

As the broad parameters of what constituted medical discourse in the nineteenth century gave way to the more specialized disciplines of psychiatry and psychoanalysis by the century's end, nosological realism was joined with case-history narrative conventions, thus constituting a new kind of writing, one that, following Freud and Sander Gilman, I have called pathography. From P. L. Jacob's Curiosités de l'Histoire de France $(1858)$ to Richard von KrafftEbing's Psychopathia Sexualis (1886); from Oskar Panizza's Pyschopathia Criminalis (1898) to Dr. Augustin Cabanès's Le Cabinet secret de l'histoire (1900); and from Havelock Ellis's Studies in the Psychology of

3o. Octave Mirbeau, "LOctogénaire," in ibid., p. 99.

31. Jacques Lacan, "The Line and the Light," in The Four Fundamental Concepts of Psycho-analysis, ed. Jacques-Alain Miller, trans. Alan Sheridan (New York: Norton, 1978), p. 101. 
Sex (1936) to Magnus Hirschfeld's Geschlechts Anomalien und Perversionen (1957), legendary biographies were pathologized; that is, they were built up as medical dossiers and collected like so many rare specimens. ${ }^{32}$ Each case study was exhibited, as in a psychohistorical museum, demonstrating individually the determinative traits of a given perversion, obsession, or paranormal idée fixe, and exemplifying as a totality the taxonomy of criminal anomaly.

Despite this wealth of material, there exists, to date, no satisfactory definition of the pathography. Freud used the term provocatively in the final chapter of his Leonardo da Vinci and a Memory of His Childhood (1910) to defend himself against the slings of idealistic biographers intent on glorifying "great men" even at the expense of truth:

- It would be futile to blind ourselves to the fact that readers to-day find all pathography unpalatable. They clothe their aversion in the complaint that a pathographical review of a great man never results in an understanding of his importance and his achievements, and that it is therefore a piece of useless impertinence to make a study of things in him that could just as easily be found in the first person one came across. But this criticism is so manifestly unjust that it is only understandable when taken as a pretext and a disguise. Pathography does not in the least aim at making the great man's achievements intelligible; and surely no one should be blamed for not carrying out something he has never promised to do. The real motives for the opposition are different. We can discover them if we bear in mind that biographers are fixated on their heroes in a quite special way. In many cases they have chosen their heroes as the subject of their studies because-for reasons of their personal emotional life-they have felt a special affection for him from the very first. They then devote their energies to a task of idealization, aimed at enrolling the great man among the class of their infantile models - at reviving in him, perhaps, the child's ideal of his father. To gratify this wish they obliterate the individual features of their subject's physiognomy; they smooth over the traces of his life's struggles with internal and external resistances, and they tolerate in him no vestige of human weakness or imperfection. They thus present us with what is in

32. The most prepossessing of all these studies from a literary point of view is Panizza's, particularly the section called "Typologie de la psychopathia criminalis." Here, in a wonderful tongue-in-cheek description of "l'état démentiel final" (the final state of dementia) awaiting the lapsed or deviating monarchist, he couched a biting critique of the German empire of William II. Seeming to anticipate twentiethcentury instances of the psychiatrization of repression, he ironically entered the term la mania anti-gouvernementalis into the lexicon of terms used to describe the mental condition of political subversives. 
fact a cold, strange, ideal figure, instead of a human being to whom we might feel ourselves distantly related. That they should do this is regrettable, for they thereby sacrifice truth to an illusion, and for the sake of their infantile phantasies abandon the opportunity of penetrating the most fascinating secrets of human nature. ${ }^{33}$

In addition to refusing the "clean," expurgated life, Freud implies that the distinguishing feature of the pathography is its attention to the sexual peculiarities of the creative artist or the minute eruptions of repressed desire in the work of art. He identifies the single most important technique developed by psychoanalysis for unlocking the "fascinating secrets of human nature" as a heightened sensitivity to detail. Noting an error made by Leonardo as to the exact time of his father's death, he remarks, "It is only a small detail, and anyone who is not a psycho-analyst would attach no importance to it," only to add didactically: "But the psycho-analyst thinks differently. To him nothing is too small to be a manifestation of hidden mental processes." ${ }^{34}$

Freud's pathography of Leonardo may be historically and comparatively situated in a canon of psychological fiction particularly popular in European literature from the end of the nineteenth century through the 1930s. When, in his study of Leonardo da Vinci, Freud angrily fended off the accusation that he had "merely written a psychoanalytic novel," one must remember the notoriety gained by the case-history novel. In England there were "coming out" works, such as E. M. Forster's Maurice and Radclyffe Hall's The Well of Loneliness. In Russia novels of mental instability, such as Gogol's Diary of a Superfluous Man and Dostoevsky's novella The Double, defined the literary vanguard. In Germany novellas of bourgeois neurosis and monomania, such as Stefan Zweig's "The Royal Game," "The Burning Secret," and "Amok," Arthur Schniztler's The Confirmed Bachelor, and Rilke's The Notebooks of Malte Laurids Brigge, directly inspired or were inspired by the burgeoning field of psychoanalysis. In France a host of minor naturalist works evoked the contagion of madness, psychosis, and hallucination. Forgotten

33. Sigmund Freud, Leonardo da Vinci and a Memory of His Childhood, Standard Edition 11:130. This passage offers an extremely rich critique of how idealization motivates literary scholarship. The case of biography is perhaps the most straightforward, but one can easily see, even in the writing of critical theory, how an author may be spurred on by his or her idealization of a mentor or rival critic.

34. Ibid., p. 119. 
plays by Alfred Binet (the same who wrote on fetishism) and André de Lorde, L'Obsession and L'Homme mystérieux, and forgotten novellas, such as Jean Lorrain's Songeuse, Maurice Quillot's L'Entraîné, Léon Hennique's Un Caractère (not to mention Maupassant's betterknown récits "Fou?" "Le Horla," "Le Docteur Heraclieus Gloss"), qualified as literary equivalents of Cesare Lombroso's "genius and madness" study (Le Génie et la folie) in their dissections of insanity and horror. ${ }^{35}$

In the Vienna Psychoanalytic Society, presided over by Freud between 1902 and 1918, the pathography flourished as a genre of psychoanalysis. In addition to his analysis of Leonardo, Freud contributed an early paper on "Psychopathic Characters on the Stage" (1905). Wilhelm Stekel's Poetry and Neurosis (1909), Isador Sadger's Heinrich von Kleist: A Pathographical-Psychological Study, Max Graf's analysis of Wagner's character as seen in The Flying Dutchman (A Contribution to the Psychology of Artistic Creation, 1911), Otto Rank's The Artist, and Theodor Reik's Arthur Schnitzler as Psychologist (1913)-all could be classed under the rubric of pathography. ${ }^{36}$

In a more contemporary critical vein, Evelyne Keitel has characterized the psychopathography as a work of fiction in which experiences such as schizophrenia, hallucination, autism, and anorexia are transcribed and transmitted through ingenious techniques of reader response:

- Psychopathographies comprise a quantity of apparently quite different texts: traditional pathographies (Freud's case histories) as well as those texts about psychoses which, as a phenomenon of contemporary literature, have not yet had the critical attention they deserve. In this book, I started out by hypothetically defining psychopathographies by two criteria, one of content and one of aesthetic response. Psychopathographies thematize psychotic personality dissolutions and/or psychotherapies, and are thus obligated to grapple with phenomena beyond the margins of discourse. The way in which a psychopathography translates psychotic phenomena into linguistic structures determines, in turn, the extent to which such a borderline situation can be conveyed, and even experienced, in the reading process. ${ }^{37}$

35. André Vial, L'Internement de Maupassant: Documents inédits (Paris, 1892).

36. For this bibliography I am indebted to Louis Rose, "The Psychoanalytic Movement in Vienna: Toward a Science of Culture" (Ph.D. diss., Princeton University, 1986).

37. Evelyne Keitel, Reading Psychosis: Readers, Texts, and Psychoanalysis, trans. Anthea Bell (Oxford: Basil Blackwell, 1989), p. 85 . 
Though Keitel's emphasis on the rhetoric of madness as a distinguishing trait of pathography is essential, I feel impelled to extrapolate the generic criteria to include: (1) the medicolegal dossier as transposed into fiction; (2) demonic hagiography as defined by the unsaintly life of civilization's greatest "perverts" (Gilles de Rais, Jack the Ripper, the Countess Bathory); (3) psychohistorical biography (Alexander the Great, Mohammed, Marie Antoinette) that focuses on the "dirty little secrets" of celebrated men and women; and (4) the tabloid story featuring scenes from the human circus: freak shows, gladiatorial sports, sagas of family members who commit unnatural acts, and so on. This is by no means an exhaustive delineation of this bastard genre of pathography, but it frames an exemplary gamut of turn-of-the-century texts that explore the logic of perversion and call for an interpretive approach amalgamating New History, close reading, and psychoanalysis. 